\title{
TwO PONTIC Rivers
}

\author{
ÍKI PONTOS IRMAĞI
}

\section{TøNNES BEKKER-NIELSEN* MARIT JENSEN**}

\begin{abstract}
The accounts of the landscape around the Iris (Yeșilirmak) and the Thermodon (Terme) given by ancient authors are diverse and often contradictory. The Periegesis of the World by Dionysius of Alexandria, a didactic poem written in the early II $^{\text {nd }}$ c. A.D., established an image of the two rivers that does not correspond to their actual characteristics. A closer study reveals that Dionysius, or possibly his source, has confused the two: the river which he describes as the Thermodon is in fact the Iris, and vice versa. This mistake was not realized by later translators (Avienus, late $\mathrm{IV}^{\text {th }}$ c. A.D.; Priscianus, VI ${ }^{\text {th }}$ c. A.D.) or commentators (Eustathius of Thessaloniki, XII ${ }^{\text {th }}$ c. A.D.) who had no first-hand knowledge of the Pontic landscape and geography.
\end{abstract}

Keywords: Pontos • Iris • Thermodon • Amazons
Öz: Iris (Yeşilırmak) ve Thermodon (Terme) nehirlerinin civarına ilişkin peyzaj hesapları antik yazarlarda çelişkili ve birbirinden farklıdır. İskenderiyeli Dionysios'un Dünyanın Tasviri adlı eserinde M.S. II. yüzyılın başlarında yazılmış olan didaktik bir şiirde her iki nehir için oluşturulan tablo onların gerçek karakteristiklerini yansıtmamaktadır. Daha yakın bir çalışma ise, Dionysios'un ya da muhtemelen onun kaynağının iki nehri karıştırdığını ortaya çıkarmıştır: onun Thermodon olarak tanımladığı nehir aslında Iris, diğeri de tam tersidir. Bu hata diğer çevirmenler tarafından (Avienus [M.S. IV. yüzyılın sonları]; Priscianus [M.S. VI. yüzyıl]) ya da eleştirmenler (Tessalonikeli Eustathius [M.S. XII. yüzyıl]) tarafından farkedilmemiştir ve Pontos coğrafyasına ilişkin ilk elden kaynak değildir.

Anahtar Kelimeler: Pontos • Iris • Thermodon • Amazonlar

\section{Introduction}

The Iris River (Yeşilirmak) and its tributaries the Lykos (Kelkit) and Skylaks (Çekerek) draw their waters from a large inland area of c. 36,100 $\mathrm{km}^{2},{ }^{1}$ stretching from the old Pontic capital of Amaseia (Amasya) in the west, to Nikopolis (Yeşilyayla) in the eastern Pontos and to Sebastopolis (Sulusaray) to the south. From the confluence of the Iris and the Lykos in the plain of Phanaroia, near the ancient city of Eupatoria/Magnopolis ${ }^{2}$, the waters find their way through the Pontic range to the coast through a series of narrow mountain gorges and emerge onto the Çarşamba Plain (the Themiskyra Plain of antiquity) some $10 \mathrm{~km}$. inland from the modern town of the same name. The upper Iris and the Lykos may have been used for navigation in antiquity - a coin of Amaseia shows

* University of Southern Denmark, DK-5230 Odense M. tonnes@sdu.dk

** University of Southern Denmark, DK-5230 Odense M. marit.privat@hotmail.com

We are grateful to Søren Lund Sørensen (Freie Universität Berlin) and Sanne Rishøj Christensen (University of Southern Denmark) for their constructive comments on earlier drafts of this paper.

1 Akbulut et al. 2009, 647.

2 Various locations have been proposed for the site of ancient Eupatoria (Olshausen 1984, 27-44; Erciyas 2006, 46) but recent discoveries by S. Lund Sørensen and the 'Where East meets West' project team, indicate a location in or near to the village of Çevresu, Tokat province. 
the personified Iris sitting beside a boat ${ }^{3}$ - but the gorges of the Pontic range effectively barred boats from making the passage from the Phanaroia to the coast ${ }^{4}$, and no ancient text identifies the Iris or its tributaries as being navigable.

Because it receives much of its water from the melting snows of the high mountains, the flow of the Iris shows marked seasonal variation, peaking in late April ${ }^{5}$. From the sedimentary bedrock through which they flow, the Iris and its tributaries collect massive amounts of light-coloured silt which remains suspended and which combines with phytoplankton to give the waters their characteristic opaque, pale green appearance (whence the modern name Yeşilirmak, "green river") ${ }^{6}$. Much of this material was formerly deposited in the estuary of the river, extending the alluvial plain seawards ${ }^{7}$. Since the direction of the coastal current is eastward, alluvial deposition was more pronounced to the east of Çarşamba. Due to the construction of hydroelectric dams, the amount of silt carried to the coast has been reduced by as much as $98 \%{ }^{8}$ and it is possible that in the near future, we shall see a regression of the coastline of the Yessilirmak Delta comparable to that which has already been observed at the mouth of the Kizllirmak ${ }^{9}$.

The Thermodon (Terme) is a much shorter river than the Iris, draining a small watershed stretching no more than $50 \mathrm{~km}$. inland from the Black Sea shore, and its discharge is correspondingly less ${ }^{10}$. The river is fed by summer rainfall as well as snowmelt from the northern face of the Pontic range. At the mouth of the Thermodon, the coastline has advanced, but this is mainly due to the vast quantity of sediment formerly discharged from the adjacent Iris river and carried eastward by the coastal current. The Thermodon itself does not transport major quantities of silt.

From any point of view, the Thermodon is less spectacular than the Iris, yet in the ancient literature, the Thermodon is by far the more prominent. Strabo's Geography lists "the most famous rivers" flowing into the Black Sea as follows: Ister (Danube), Tanais (Don), Borysthenes (Dnepr), Hypanis (Bug), Phasis (Rioni), Thermodon (Terme), Halys (Kizılırmak) ${ }^{11}$. In his Chorographia, Pomponius Mela ( $\mathrm{I}^{\text {st }}$ c. A.D.) mentions the Thermodon, Parthenios (Bartin), Halys and Phasis, but the Iris is passed over in silence ${ }^{12}$. A treatise entitled, On rivers and mountains, from the $\mathrm{II}^{\text {nd }}$ c. A.D., formerly attributed to Plutarch, includes the Thermodon, Sangarios (Sakarya) and Phasis, along with the Ganges, Danube, Nile and others. An anonymous early East Roman (Byzantine) author lists the Phasis, Thermodon and Sangarios as the largest rivers of Asia draining into the Black Sea ${ }^{13}$.

\section{The Amazons}

What first drew the attention of ancient authors was not the Thermodon River as a geographical

3 Imhoof-Blumer 1923, 257 no. $210=$ Dalaison 2008, 79 type 17 no. 100.

4 On the navigability of the Iris, also Lebreton 2014, with further references. On the obstacle posed by the steep gorge of the Iris downstream from Eupatoria-Magnopolis, Akbulut et al. 2009, 655; Roelens-Flouneau 2015.

Hay 1994, 280.

Soylu - Gönülol 2003, 17.

Hay 1994, 279 and table 2.

8 Hay 1993, 280-81; Akbulut et al. 2009, 658-659.

9 Kökpınar et al. 2007, 446; Akbulut et al. 2009, 655.

10 Weimert 1984, 112-113; Güler 2013, fig. 4.

11 Strab. VII. 3. 6.

12 Mela I. 105-8.

13 Geographiae expositio compendiaria, I. 29 = Müllerus 1965, 501-502. 
feature, which at the most would place it on a par with the Iris - Ksenophon states that the Thermodon and the Iris are each three plethra in width ${ }^{14}$ - but its association with the mythical female warriors, the Amazons. The Amazons appear in Greek literature as early as Homer, and Herodotus locates their homeland on the banks of the Thermodon ${ }^{15}$, a theme taken up by Apollonios of Rhodes (III ${ }^{\text {rd }}$ c. B.C.) in his narrative of Jason's and his companions' voyage along the Black Sea coast to Kolkhis in search of the Golden Fleece.

While still in the Propontis, Jason's men encounter the seer Phineus, who describes the Black Sea and the voyage that awaits them: sailing along the coast and having passed the "roaring waters of the Halys" they will come to "a smaller stream, the Iris, rolling white-eddied into the sea" 16 . After the Iris there is a headland, then there is the mouth of the Thermodon, where the river meets the sea having

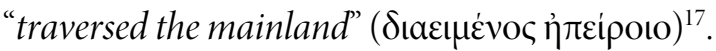

Later in the story, the Argonauts have entered the Black Sea and Phineus' prophecy has become real. Now, the heroes have ...

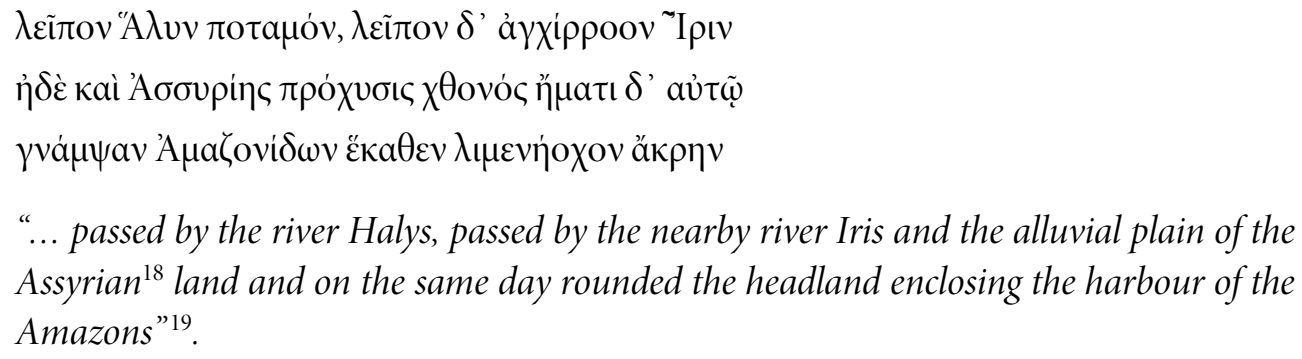

The sea is rough, so the Argonauts "there put to shore in the gulf, at the mouths of the Thermodon"

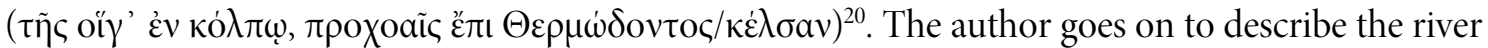
in greater detail: from its spring in the lofty mountains "which are called the Amazonian mounts" the Thermodon flows into a country of hills and valleys where its stream divides into no less than ninety-four branches, some of which drain away into the sands, while others eventually reach the Black Sea ${ }^{21}$. Among these rivers and valleys live the Amazons, "dwelling not together in one city, but

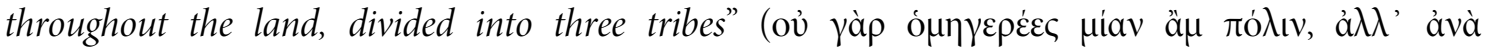

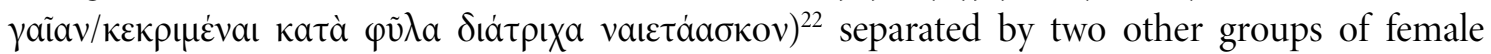
warriors, the Lykastai and the "javelin-throwing Chadesiai" 23 .

\section{Strabon and Arrian}

Strabon of Amaseia wrote his Geography shortly after the beginning of our era. As a native of Pontos, he is the first to provide an eyewitness account of the two rivers. (Ksenophon passed

$14 \quad$ Ksen. Anab. V.6.9.

15 Hdt. IV. 110.

16 Apoll. Rhod. argon. II. 366-368.

17 Apoll. Rhod. argon. II. 372.

18 Several ancient authors mention tribes of northern Anatolia known variously as Assyrians, Syrians or Leukosyrians (“white Syrians”), e.g., Hdt. II. 104. 3; Strab. XII. 3. 9; Plin. nat. VI. 3.

19 Apoll. Rhod. argon. II. 964.

20 Apoll. Rhod. argon. II. 970-71.

21 Apoll. Rhod. argon. II. 974-984.

22 Apoll. Rhod. argon. II. 996-97.

23 Apoll. Rhod. argon. II. 999-1000. 
through the region ${ }^{24}$, but never saw the rivers for himself). Loath, perhaps, to ignore a myth that had made his Pontic homeland famous, Strabon throws a passing reference refers to "Themiskyra, the home of the Amazons", then goes on to describe the rivers flowing through it:

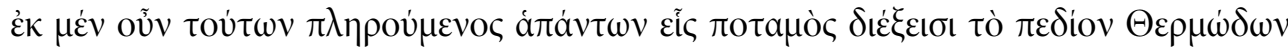

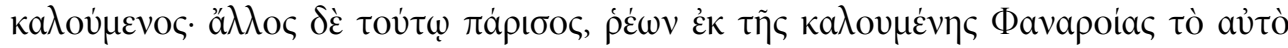

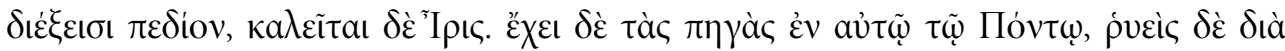

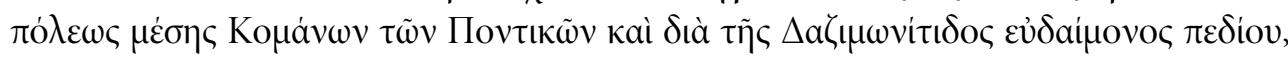

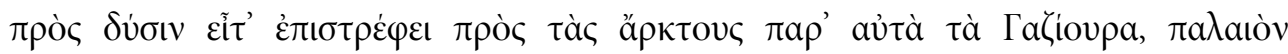

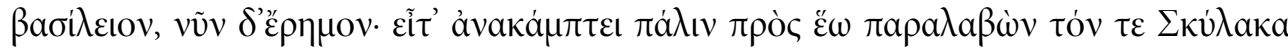

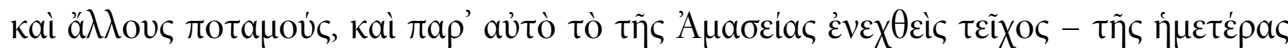

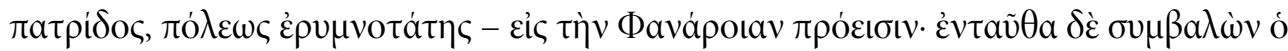

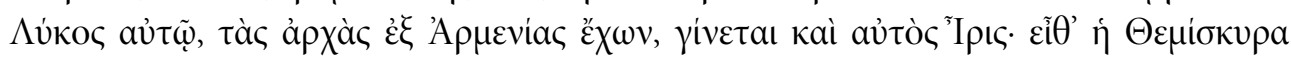

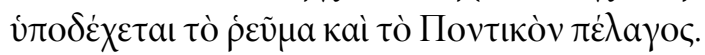

"So one river, called the Thermodon, being supplied by all these streams, flows out through the plain; and another river similar to this, which flows out of Phanaroia, as it is called, flows out through the same plain, and is called the Iris. It has its sources in Pontos itself, and, after flowing through the middle of the city Komana in Pontos and through Dazimonitis, a fertile plain, towards the west, then turns towards the north past Gazioura itself, an ancient royal residence, though now deserted, and then bends back again towards the east, after receiving the waters of the Skylaks and other rivers, and after flowing past the very wall of Amaseia, my fatherland, a very strongly fortified city, flows on into Phanaroia. Here the Lykos River, which has its beginnings in Armenia, joins it, and itself also becomes the Iris. Then the stream is received by Themiskyra and by the Black Sea" ${ }^{\prime 25}$.

Like Strabon, Arrian (II ${ }^{\text {nd }}$ c. A.D.) was a native of the region, born in Nikomedia and the author of a History of Bithynia which is now lost. His Periplus of the Euxine is dedicated to the Emperor Hadrian and its style is matter-of-fact, almost laconic. From the text it is evident that much of what Arrian has to say is based on autopsy, though occasionally he also draws on the literary tradition. Although he mentions the Amazons, he takes care to distance himself one step further than Mela from the stories of the female warriors, which are presented as not only in the past, but based on hearsay:

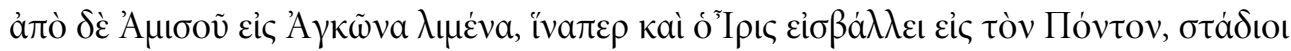

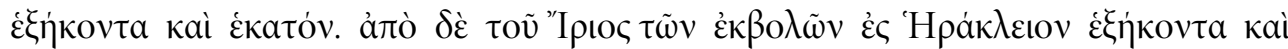

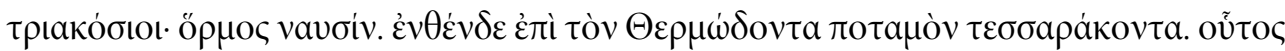

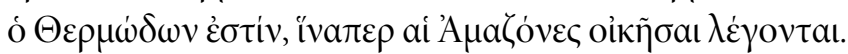

"From Amisos to the port of Ankon, where the river Iris flows into the Black Sea, 160 stadia. From the mouths of the Iris to the Herakleion, a port, 360 stadia. From here to the river Thermodon, 40 stadia. This is the Thermodon by which the Amazons are said to

24 Ksenophon (Anab. V. 6. 9) reproduces the words of his informant Hekatomnymos; he himself never saw the Thermodon or the Iris at close hand.

25 Strab. XII. 3. 15. 
have dwelt"26.

Another Periplus of the Black Sea purports to be from the hand of Arrian, but in reality it is a patchwork of quotations from Arrian himself and other authors, probably compiled in the second half of the $\mathrm{VI}^{\text {th }} \mathrm{c}$. A.D. The Thermodon is said to be $\pi \lambda \omega \tau$ óc, navigable, a piece of information that is found in no other extant source ${ }^{27}$. (Quintus of Smyrna, writing in the $\mathrm{IV}^{\text {th }}$ c. A.D., describes the Thermodon as sủpútropoc, "wide-flowing"28, but this is surely derived from Apollonios).

\section{The Early Latin Tradition}

The Latin geographical writers of the ${ }^{\text {st }}$ c. A.D., Pomponius Mela and the elder Pliny, both describe the landscape around the Thermodon. Mela's description is clearly dependent on Apollonios and includes the Amazons - to which, however, he refers in the past tense (fuere):

Secundum Halyn urbs est Lycasto, ad Thermodonta campus. In eo fuit Themiscurum oppidum, fuere et Amazonum castra, ideo Amazonium vocant.

"After the Halys comes the city Lykastos (and) on the Thermodon a plain. In this were formerly the town Themiskyra and a fortress of the Amazons; for this reason they call it Amazonion"29.

Writing a generation after Mela, the elder Pliny prefaced the sixth book of his Natural History, on the geography of Asia, with a long list of sources which includes Mela, but neither Apollonios nor Strabon. Pliny's description covers not only the Pontic coast, but also the interior:

Cappadocia intus habet coloniam Claudi Caesaris Archelaidem quam praefluit amnis Halys, oppida Comana, quod (sc. praefluit) Salius, Neocaesaream, quod Lycus, Amasiam, quod Iris ... A Neocaesarea supra dicta Minorem Armeniam Lycus amnis disterminat. Est et Coeranus intus clarus., in ora autem ab Amiso oppidum et flumen Chadisia, Lycastum, a quo Themiscyrena region, Iris flumen deferens Lycum. Civitas Ziela intus, nobilis clade Triarii et victoria C. Caesaris. In ora amnis Thermodon ortus ad castellum quod vocant Phanorian, praeterque radices Amazoni montis lapsus. Fuit oppidum eodem nomine et alia quinque, Amazonium, Themiscyra, Sotira, Amasia, Comana, nunc Matium.

"Cappadocia includes Archelaïs, a colony of Claudius Caesar, by which the Halys flows, and the towns Komana, by which the Salius flows, Neokaisareia, by which the Lykos, Amaseia, by which the Iris ... From Neokaisareia, previously mentioned, the Lykos forms the boundary of Armenia Minor. In the interior, the Koiranos is also well known and on the coast from (i.e. east of) Amisos the town and river Khadisia, and Lykastos where the territory of Themiskyra begins. The river Iris of which the Lykos is a tributary. The city of Zela in the interior, famous for the defeat of Triarius and the victory of C. Caesar. On the coast, the Thermodon river which originates at the fortress which they call Phanoria and falls at the foot of mount Amazonios. There was formerly a town of the same name and

\footnotetext{
Arr. Periplus 15.

Bekker-Nielsen 2016.

Q. Smyrn. Posthom. I. 18

29 Mela I. 105.
} 
five others: Amazonion, Themiskyra, Sotira, Amaseia and Komana, now known as Mation"30.

Although part of his description resembles that of Mela, Pliny takes no interest in the Amazons. The information on the hydrology of the region may originate from Eratosthenes, who is listed among Pliny's sources. Eratosthenes' Geographika has not been preserved, but is known through quotations in other authors, notably Strabon, who did not think highly of Eratosthenes and rarely misses a chance to point out an error in his work. Thus in book XI, Strabon describes the rivers of Armenia,

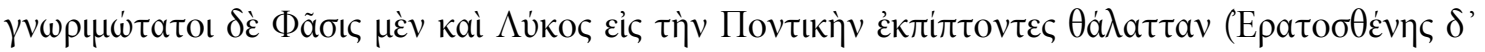

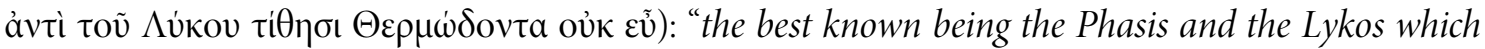
flow into the Pontic Sea; but Eratosthenes wrongly has Thermodon instead of Lykos" ${ }^{1}$.

The similarity in name between 'the fortress which they call Phanoria' is suggestive. If both refer to the same place, i.e. if Phanoria was located in the plain of the $\operatorname{Lykos}^{32}$, then Pliny has misplaced the source of the Thermodon, as did Eratosthenes. As we shall see below, other writers also have had difficulty distinguishing the Thermodon from the Iris/Lykos.

\section{Mistaken Identities}

The short treatise On rivers and mountains belongs to an entirely different genre: paradoxography, the description of natural wonders and phenomena. The text is not, as was once believed, from the hand of Plutarch, but is of his period, i.e., the $\mathrm{I}^{\text {st }}$ or $\mathrm{II}^{\text {nd }} \mathrm{c}$. A.D. It is preserved in a single manuscript and most of the description of the Thermodon has been lost. What remains is, however, intriguing enough. Our author, evidently less concerned with reality than with creating a credible geographical background, places the river on the northern shore of the Black Sea ${ }^{33}$ :

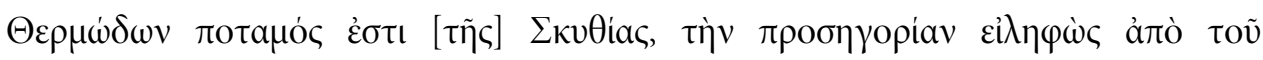

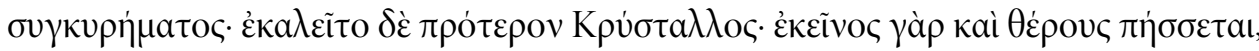

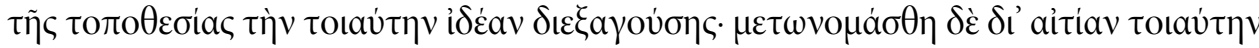
$\cdots$

"Thermodon is a river of Skythia, formerly called Krystallos, taking its name from a peculiarity: it freezes in the summer, in consequence of its location. For this reason it was renamed..."34.

Although a literary tradition, going back as far as Herodotus ${ }^{35}$, connects the Amazons with the Sauromatai on the northern Black Sea shore, there is nothing to suggest that the Anatolian Thermodon had a Skythian doublet of the same name. Probably our author transposed the Thermodon acoss the Black Sea from Anatolia to Skythia -famous for its harsh climate- to support his claim that the waters of the river could freeze even in summer.

30 Plin. nat. VI. 3-4.

$31 \quad$ Strab. XI. 14.7.

32 Thus Herrmann 1938, 1759, but rejected by Olshausen - Biller 1984, 155.

33 For the mythical connection between the river Thermodon, the Amazons and the Skythians, see Ilyushechkina 2010, 241-242

34 Ps.-Plut. De fluviis 15. The same author credits many other rivers with producing stones. According to Pliny (nat. XXXVII. 37), blue iaspis (probably chalcedony) was found on the banks of the Thermodon and other north Anatolian rivers; see also Ilyushechkina 2010, 291.

35 Hdt. IV. 110-113. 
The same theme is taken up, with variations, in the Periegesis, a description of the world in hexameters, composed during the reign of Hadrian by the author known as Dionysios the Periegete or Dionysios of Alexandria ${ }^{36}$. Dionysios shared Pseudo-Plutarch's interest in stones and is credited with having written a $\Lambda$ itaka (now lost). Unlike Pseudo-Plutarch, however, he places the Thermodon and the Iris in their correct place on the southern shore of the Euxine.

The following is what Dionysios has to say about the two rivers:

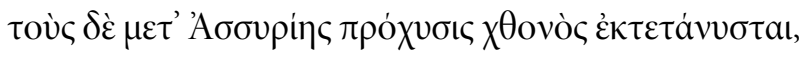

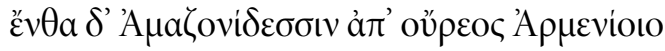

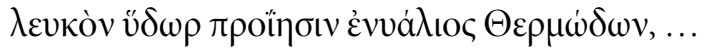

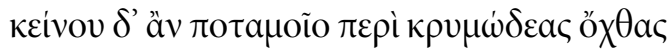

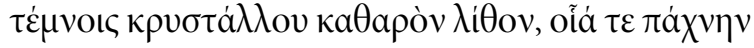

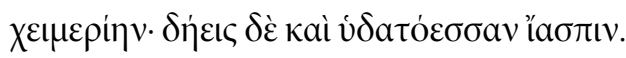 \\ "I Iıı $\delta$ ' \\ "[772] Then stretch the Assyrian land's alluvial plains \\ Where for the Amazons from the Armenian Mount \\ The martial Thermodon sends its white water.... \\ [780] Around that river's icy banks, you could \\ Extract pure rock-crystal, like hoary frost \\ In winter; and you'll find pellucid jasper. \\ Next, Iris sends clear water to the sea" ${ }^{\prime 3}$.
}

The debt to Apollonios is obvious, but where the Argonautica placed the source of the Thermodon "in what is called the Amazonian Mount" 38 , the Periegesis has "the Armenian Mount". The two most recent commentators on this passage ${ }^{39}$ both point to the parallel case of Eratosthenes who was criticized by Strabon for confusing the Armenian source of the Lykos and the 'Amazonian' source of the Thermodon. As a closer reading makes clear, Dionysios' error is at once more banal and more serious: not only the sources, but the rivers themselves have been switched around.

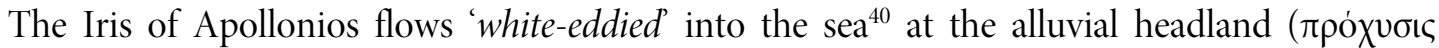
$\chi \theta$ ovóc) of the Assyrians ${ }^{41}$; though Apollonios does not says so, its waters (those of the Lykos) come from Armenia. In the version of Dionysios, it is the waters of the Thermodon that are white, while

36 On the date and identity of the author, see the discussion by Ilyuschechkina 2010, 30-33 (with references); Lightfoot 2014, 4.

37 Dion. Perieg. 772-74; 780-86; translation adapted from Lightfoot.

38 Apoll. Rhod. argon. II. 977.

39 Ilyuschechkina 2010, 290; Lightfoot, Dionysius ad loc. (p. 434).

40 Apoll. Rhod. argon. II. 368.

${ }^{41}$ Apoll. Rhod. argon. II. 964. 


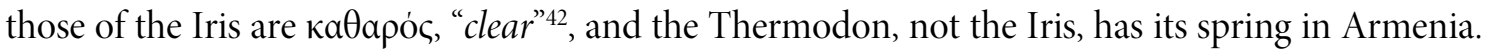

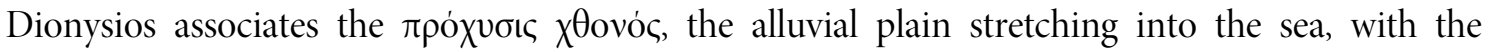
Thermodon, not the Iris - against the account of Apollonios (and reality).

How did this inversion of the two rivers come about? Since the description of Apollonios runs from west to east, Dionysios, who worked in the opposite direction, may simply have made a mistake when excerpting the Argonautica. In any case the image of the turgid white water naturally

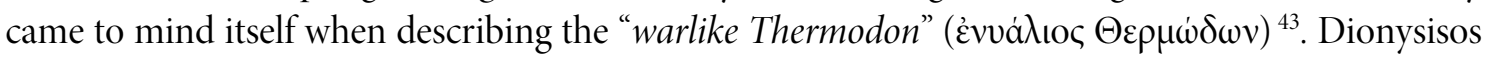
had no first-hand knowledge of the Pontic rivers, while even in the case of those with which he or his readers might be familiar, he allows himself a good deal of poetic licence: the waters of the Tiber,

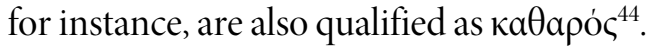

The Periegesis of Dionysios enjoyed enormous popularity throughout late Antiquity ${ }^{45}$ and was twice translated into Latin, first by Avienus ( $V^{\text {th }}$ c. A.D.) and again by Priscian (VI ${ }^{\text {th }}$ c. A.D.). Eustathius, Bishop of Thessaloniki in the later XII ${ }^{\text {th }}$ c., devoted part of his working life to writing commentaries on four important literary works: the Iliad, the Odyssey, the poems of Pindar - and the Periegesis of Dionysios ${ }^{46}$. As late as the sixteenth and seventeenth centuries, the Greek text or its Latin versions were being published and studied throughout Europe ${ }^{47}$. Thus Dionysios' inverted description of the two Pontic rivers came to be received wisdom for close to 1,500 years.

In lines 780-783, we were told that the Iris has a "clear stream" (кaAapòv póov). whereas the

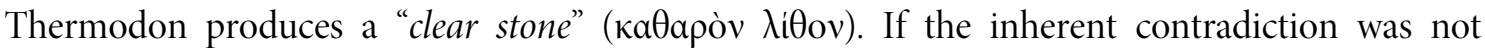
apparent to Dionysios himself, it was evidently noticed by Avienus, who chose to omit lines 780 to 782 from his Latin version of the Periegesis ${ }^{48}$. While Avienus readily accepts Dionysios' characterization of the Iris as clear (purus) $)^{49}$ he does not share his description of the Thermodon as 'warlike'; instead, he refers once to the 'broadly rising' (late surgens) ${ }^{50}$ Thermodon and on another occasion to the "streams of the wide Thermodon", vasti ... flumina Thermodontis ${ }^{51}$, recalling Apollonios and the "wide-flowing" river described by Quintus of Smyrna.

In the Latin version of the $\mathrm{VI}^{\text {th }} \mathrm{c}$. translator, Priscian, the descriptions are reversed. Priscian's Thermodon is every bit as warlike as that of Dionysios:

.. qua gurgite vasto

inter Amazonidas Thermodon, Martius amnis

42 Dion. Perieg. 783.

43 Dion. Perieg. 774 (Ilyushechkina 2010: 'mörderisch'). For a rather more complex interpretation of this passage, see Lightfoot 2014, 434: "pouring forth its white Indo-Aryan waters, the river follows a cartographic route from the Armenian mountains to the sea".

$44 \quad$ Dion. Perieg. 352.

45 Ilyuschechkina 2010, 304-309.

46 Kazhdan 1984, 132-133.

47 Amato 2005, 54; 180-181.

48 Av. Or. Ter. 955-56. The anonymous scholiast on Dionysios also notes the problem of the 'white' Thermodon producing a clear stone; he briefly considers the emendation "warm water" ( $\theta \varepsilon \rho \mu$ òv v́ $\delta \omega \rho)$ but rejects it: Scholia in Dionysium ad 774.

49 Av. Or. Ter. 956.

50 Av. Or. Ter. 950.

51 Av. Or. Ter. 856. 
Armenium linquens montem descendit in aequor.

"... where, whirling wildly,

the Thermodon, river of Mars, coming from the Armenian mount

flows down to the plain among the Amazons" 52 .

Despite its violent nature, Priscian's Thermodon was able to produce rock crystal "along its icy banks": rigidas prope frigore ripas ${ }^{53}$. On the other hand, the Iris, though flowing "in a steady stream from the hills to the sea": Iris continuo liquidus decurrit in aequor ${ }^{54}$, is not said to be purus.

The story of the Thermodon's crystal-producing qualities is repeated by Eustathius of Thessaloniki in his commentary on Diogenes' Periegesis, adding that the Thermodon was formerly called Krystallos because it "freezes in summer, in consequence of its location" - a word-for-word quotation from pseudo-Plutarch which Eustathius prudently qualifies with the reservation $w \varsigma$ of

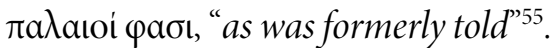

\section{Concluding Remarks}

While early descriptions of the Iris and the Thermodon were based, albeit in most cases indirectly, on actual experience, later writers from Pseudo-Dionysios onwards viewed the Pontic shore more as a literary landscape (like the worlds of J. R. R. Tolkien or Harry Potter) than as a real space, and geography more as a literary form than as a branch of science. Factual geography, as Mela laments in the introduction to his Chorography, was "laborious work with little opportunity for eloquence": impeditum opus et facundiae minime capax ${ }^{56}$ and the result was not in great demand among the educated public, which much preferred the elegant poetry of Dionysios. Apparently no one found it worth their while to compare the text of the geographical writers with the actual landscape, and despite its inconsistencies, the description of Dionysios remained unchallenged for more than 1,500 years ${ }^{57}$.

52 Prisc. Perieg. 747-749.

53 Prisc. Perieg. 752-755.

54 Prisc. Perieg. 749.

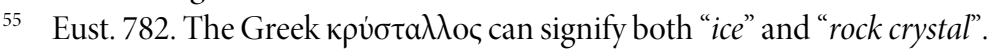

56 Mela I. 1.

57 The first modern researcher to draw attention to the discrepancy between the waters of the Iris as described by Dionysios and its actual appearance was W. Hamilton (1842, I, 283), who describes the river as "muddy and yellow". The problem was dismissed by E. Delage $(1930,170)$ as "une invention poétique". 


\section{BIBLIOGRAPHY}

\section{Ancient Sources}

Apoll. Rhod. argon.

Arr. Periplus

Av. Or. Ter.

Dion. Perieg.

Eust.

Hdt.

Mela

Plin. nat.

Prisc. Perieg.

Ps.-Plut. De fluviis

Q.Smyrn. Posthom.

Strab.

Ksen. Anab.
(= Apollonios Rhodios, Argonautica)

Apollonius von Rhodos, Das Argonautenepos Apollonius von Rhodos, Das Argonautenepos. Ed. - Trans.: R. Glei - S. Natzel-Glei. Darmstadt 1996.

(= Arrian, Periplus Ponti Euxini)

Flavii Arriani Quae Exstant Omnia. Ed. A. G. Roos, vols. I-II. Leipzig 1968 (Bibliotheca Teubneriana).

(= Avienus, Descriptio Orbis Terrae)

La Descriptio Orbis Terrae d' Avienus: Edition Critique. Trans.: P. van de Woestijne. Bruges 2005.

(= Dionysios, Oikoumenes Periegesis)

Dionysius Periegetes, Description of the Known World. Trans. - Com.: J.

L. Lightfoot. Oxford 2014.

(= Eustathius, Commentary)

Geographi Graeci Minores. E Codicibus Recognovit, Prolegomenis Annotatione Indicibus Instruxit, Tabulis Aeri Incises Illustravit, Volume II. Ed. C. Müllerus. Hildesheim (1965) 201-407.

(= Herodotos, Historiai)

Herodotos, Herodoti Historiae I, libros I-IV Continens. Ed. H. B. Rosén. Leipzig 1987 (Bibliotheca Teubneriana).

(= Pomponius Mela, De Chorographia)

Pomponius Mela, Kreuzfahrt Durch die Alte Welt. Trans.: K. Brodersen. Darmstadt 1994.

(= G. Plinius Secundus, Naturalis Historia)

C. Plinii Secundi Naturalis Historiae XXXVII. Ed.: C. Mayhoff. Berlin 1897-1906.

(= Priscianus, Periegesis)

Geographi Graeci Minores. E Codicibus Recognovit, Prolegomenis Annotatione Indicibus Instruxit, Tabulis Aeri Incises Illustravit, Volume II. Ed. C. Müllerus. Hildesheim (1965) 190-199.

(= Pseudo-Plutarkhos, De Fluviis)

Fiumi e Monti. Testo critico, Traduzione e Commento a Cura. Trans. Com.: E. Calderón Dorda, A. De Lazzer - E. Pellizer. Naples 2003.

Geographi Graeci Minores. E Codicibus Recognovit, Prolegomenis Annotatione Indicibus Instruxit, Tabulis Aeri Incises Illustravit, Volume II. Ed. C. Müllerus. Hildesheim (1965) 637-665.

(= Quintius Smyrnaeus, Posthomerica)

Quinti Smyrnaei Posthomerica. Ed.: G. Pompella. Hildesheim 2002.

(= Strabon, Geographika)

Strabons Geographika. Trans. - Com.: S. Radt. Göttingen 2004 -2011. The Geography of Strabo. Trans.: H. L. Jones, vols. I-VIII. London - New York 1917-1932 (The Loeb Classical Library).

(=Xenophon, Anabasis) 
Xenophon, Anabasis der Zug der Zehntausend. Ed. - Trans.: W. Müri - B. Zimmermann. Düsseldorf 2002.

\section{Modern Literature}

Akbulut et al. 2009

Amato 2005

Bekker-Nielsen 2016

Dalaison 2008

Delage 1930

Erciyas 2006

Güler 2013

Hamilton 1842

Hay 1994

Herrmann 1938

Ilyushechkina 2010

Imhoof-Blumer 1923

Kazhdan 1984

Kökpınar et al. 2007

Lebreton 2014

Müllerus 1965

Olshausen - Biller 1984

Roelens-Flouneau 2015
N. Akbulut, B. Serdar, A. Akbulut - Y. Șahin, "Rivers of Turkey". Eds. K. Tockner, U. Uehlinger - C. T. Robinson, Rivers of Europe. Amsterdam (2009) 643-672.

E. Amato, Dionisio di Alessandria: Descrizione Della Terra Abitata. Milan 2005.

T. Bekker-Nielsen, "Navigable Rivers of Northern Anatolia". Ed. A. Dan, The Black Sea (4 $4^{\text {th }}-7^{\text {th }}$ century AD): The End of the Ancient World, Beginning of a New Order?. Stuttgart 2016 (forthcoming).

J. Dalaison, L'atelier d'Amaseia du Pont: Recherches Historiques et Numismatiques. Bordeaux 2008.

E. Delage, La Géographie dans les Argonautiques d'Apollonios de Rhodes. Paris 1930.

D. B. Erciyas, Wealth, Aristocracy and Royal Propaganda under the Hellenistic Kingdom of the Mithradatids. Leiden 2006.

M. Güler, "Stream Network Creation and Watershed Definition by Using Digital Elevation Model for Samsun, Turkey". Journal of Food, Agriculture \& Environment 11 (2013) 1315-1320.

W. Hamilton, Researches in Asia Minor, Pontus and Armenia: With Some Account of their Antiquities and Geology I-II. London 1842.

B. J. Hay, "Sediment and Water Discharge of Turkish Black Sea Rivers Before and After Hydropower Dam Construction". Environmental Geology 23 (1994) 276-283.

A. Herrmann, "Phanaroia". RE XIX (1938) 1759.

E. Ilyushechkina, Studien zu Dionysios von Alexandria, Unpublished $\mathrm{PhD}$ Dissertation, University of Groningen. Groningen 2010.

F. Imhoof-Blumer, "Fluß- und Meeresgötter auf Griechischen und Römischen Münzen”. Revue suisse de Numismatique 23 (1923) 173-421.

A. Kazhdan, Studies on Byzantine Literature of the Eleventh and Twelth Centuries. Cambridge 1984.

M. A. Kökpınar, Y. Darama - I. Güler, "Physical and Numerical Modeling of Shoreline Evaluation of the Kizllırmak River Mouth, Turkey". Journal of Coastal Research 23 (2007) 445-456.

S. Lebreton, "Quelques Remarques à Propos de la Navigation sur les Fleuves Anatoliens (III)". Dialogues d'histoire Ancienne 40/2 (2014) 257268.

C. Müllerus, Geographi Graeci Minores. E Codicibus Recognovit, Prolegomenis Annotatione Indicibus Instruxit, Tabulis Aeri Incises Illustravit II. Hildesheim 1965.

E. Olshausen - J. Biller, Historisch-Geographische Aspekte der Geschichte des Pontischen und Armenischen Reiches, 1. Untersuchungen zur Historischen Geographie von Pontos unter den Mithradatiden. Wiesbaden1984. H. Roelens-Flouneau, "Remarques sur la Navigabilité des Fleuves d'Asie 
Soylu - Gönülol 2003

Mineure dans l'Antiquité". Eds. A. Dan - S. Lebreton, Études des Fleuves d'Asie Mineure: Une Première Approche. Arras 2015 (in press).

E. N. Soylu - A. Gönülol, "Phytoplankton and Seasonal Variations of the River Yeşilırmak, Amasya, Turkey”. Turkish Journal of Fisheries and Aquatic Sciences 3 (2003) 17-24. 